\title{
Variable inter and intraspecies alkaline phosphatase activity within single cells of revived dinoflagellates
}

\author{
Mathias Girault ${ }^{1} \cdot$ Raffaele Siano $\mathbb{1}^{2} \cdot$ Claire Labry $\mathbb{B}^{2} \cdot$ Marie Latimier $^{2} \cdot$ Cécile Jauzein $^{2} \cdot$ Thomas Beneyton $^{1}$. \\ Lionel Buisson ${ }^{1} \cdot$ Yolanda Del Amo $\mathbb{1}^{3} \cdot$ Jean-Christophe Baret $\mathbb{B}^{1,4}$
}

Received: 18 June 2020 / Revised: 4 January 2021 / Accepted: 20 January 2021 / Published online: 10 February 2021

(c) The Author(s), under exclusive licence to International Society for Microbial Ecology 2021

\begin{abstract}
Adaptation of cell populations to environmental changes is mediated by phenotypic variability at the single-cell level. Enzyme activity is a key factor in cell phenotype and the expression of the alkaline phosphatase activity (APA) is a fundamental phytoplankton strategy for maintaining growth under phosphate-limited conditions. Our aim was to compare the APA among cells and species revived from sediments of the Bay of Brest (Brittany, France), corresponding to a preeutrophication period (1940's) and a beginning of a post-eutrophication period (1990's) during which phosphate concentrations have undergone substantial variations. Both toxic marine dinoflagellate Alexandrium minutum and the nontoxic dinoflagellate Scrippsiella acuminata were revived from ancient sediments. Using microfluidics, we measured the kinetics of APA at the single-cell level. Our results indicate that all S. acuminata strains had significantly higher APA than A. minutum strains. For both species, the APA in the 1990's decade was significantly lower than in the 1940's. For the first time, our results reveal both inter and intraspecific variabilities of dinoflagellate APA and suggest that, at a half-century timescale, two different species of dinoflagellate may have undergone similar adaptative evolution to face environmental changes and acquire ecological advantages.
\end{abstract}

\section{Introduction}

Microphytoplankton abundances, community structure and species ecological niches are commonly reported to change at ocean surfaces in response to modified environmental conditions [1]. These changes can be associated with the ability of the microorganisms to adapt their physiology in

Supplementary information The online version contains supplementary material available at https://doi.org/10.1038/s41396021-00904-2.

Raffaele Siano

raffaele.siano@ifremer.fr

$\triangle$ Jean-Christophe Baret

jean-christophe.baret@u-bordeaux.fr

1 Univ. Bordeaux, CNRS, CRPP, UMR5031, 33600 Pessac, France

2 Ifremer, DYNECO, F-29280 Plouzané, France

3 Université de Bordeaux, UMR CNRS 5805 EPOC, Station Marine d'Arcachon, 33120 Arcachon, France

4 Institut Universitaire de France, 75005 Paris, France order to maintain their resilience or spread in the environment [2-4]. Physiological responses of phytoplankton to environmental changes are generally estimated by the analysis of relatively few biological parameters in a limited number of cultivated species and strains. For a single strain in standard culture and analytical conditions, these estimates integrate the combined responses of hundreds of thousands of cells within a phytoplankton culture. This approach is limited because it overlooks cellular adaptations at the single-cell level, which are crucial for explaining changes in species distribution and phenology [5-9]. The single phytoplankton cell adaptation is a critical and a complex problem, especially given that several studies report that longterm acclimation and/or genetic selection can contribute to the maintenance of population fitness under environmental change scenarios $[10,11]$. In addition, other studies suggest that both physiological adaptations and phenotypic variability of the cells can be insufficient for survival through environmental changes [12, 13].

Physiological adaptations of phytoplankton species are classically studied by monitoring variations in biological parameters (e.g. growth rate, photosystem) under culture conditions reproducing environmental change scenarios 
[14]. Even though these approaches can demonstrate how phytoplankton respond to changes in temperature, nutrients and heavy metals, they remain limited to short-term incubations (e.g. weeks or months) because phytoplankton experiments are cumbersome to be carried out for longer periods [14-17]. For studying long-term physiological variations within phytoplankton species, an innovative approach consists of comparing biological functions among strains of species revived from sediments of different ages. These strains are obtained from the germination of cysts that were stored in ancient sediments [18, 19]. Protected by a resistant biopolymer wall, the genomes and the physiological constants of cells are theoretically well preserved [20]. Consequently, these sediment archives become "time capsules" that contain populations from the past [21, 22]. The revived cells can be cultivated under different environmental conditions, including nutrient starvation scenarios, and physiological indicators of the biological function of interest (e.g. nutrient uptake) are monitored and compared among strains [20]. The differences in biological function indicators within strains of different ages can reflect adaptations of the corresponding populations from distinct time periods.

Phosphate concentration is known to shape the structure of marine planktonic communities [23]. A low concentration of phosphate is generally reported to limit cell abundances and species distributions in many marine or coastal ecosystems [24-26]. To survive phosphate depletion, microorganisms, such as diatoms and dinoflagellates can activate a set of enzymes, such as the alkaline phosphatases (AP), to use dissolved organic phosphorus instead of phosphate $[27,28]$. Induction of extracellular AP is linked to the physiological conditions of the cells and is used as an indicator of phosphate stress in phytoplankton [29]. Here we focus on extracellular AP activity (APA) because a part of the intracellular AP can be constitutive, and substrate used for the determination of enzyme activity can be in competition with acid phosphatases involved in cellular processes not linked to cellular P-stress status [27, 30, 31]. In general, APA is determined using fluorescent substrates in bulk experiments $[32,33]$ and the fluorescence measurements are not species-specific. Although size fractionation through filtration separates free-bacteria from microphytoplankton, both living and dead cells are integrated in such enzymatic assays, which leads to an underestimation of the APA measured in the sample. Moreover, the presence of free AP, which is released by cell lyses, can overestimate APA in the sample. To limit these potential biases, microfluidics and image processing algorithms have been recently combined in order to measure APA at single phytoplankton cell levels [34].

In this study, we demonstrate a new microfluidic platform that micro-compartmentalises micron-sized droplets of cells from suspension. By sorting the water-in-oil droplets containing dinoflagellates, the APA assay is performed at the single-cell level and only counts cells of interest. To consider the potential buffer effect of the intracellular phosphorus (P) pool on the APA, we monitor the expression of APA during consecutive days, up to 7 days, and compare APA at the maximum expression. We used this new approach to analyse extracellular APA for single living phytoplankton cells and compare strains of different species and ages. We used two dinoflagellate species (i.e. Alexandrium minutum and Scrippsiella acuminata) revived from two distinct sediment layers of a core sampled in the coastal environment of the Bay of Brest (France). These two sampling layers corresponded to a pre-eutrophication period with low human P loadings (1940's) and a start of posteutrophication period for P supplies (1990's). We explored the variability of APA among cells of a same strain (intraclonal), among strains of the same species (intraspecies), and between species (inter-species). Finally, we explored APA modification at a timescale of $\sim 50$ years, a period of important changes in agricultural activities on the coastal land of the Bay of Brest. From our results, we hypothesise a co-evolving adaptations scenario of two different dinoflagellate species to the environmental variations in terms of phosphorus availability occurring in the Bay of Brest during the 1940-90 period.

\section{Materials and methods}

\section{Phytoplankton culture establishment and sample preparation}

By using a Kullenberg corer, a sediment core (KS06) was sampled on-board of the R/V Thalia on the April 25th, 2017 in the Bay of Brest $\left(48^{\circ} 22^{\prime} 52.74^{\prime \prime} \mathrm{N}-04^{\circ} 26^{\prime} 54.60^{\prime \prime}\right.$ W Brittany, France). The core was collected near the Brest harbour in a non-dredged area with a low sedimentation rate, at a water depth of $7.10 \mathrm{~m}$ (Fig. 1). The sediment core (3.44 m long) was immediately extruded from the Plexiglas tube and sliced into 1-cm layers. Aliquots of sediments were used for dating as previously described [19,21]. Materials for dinoflagellate cyst germination were stored in $50 \mathrm{~mL}$ Nalgene tubes at $4{ }^{\circ} \mathrm{C}$ in the dark and without oxygen. Aliquots of the sediment-sieved fraction $25-100 \mu \mathrm{m}$ were suspended in a culture K medium (EDMK/5; ref. [35]) and cell germinations were monitored daily with light microscopy. Single germinated cells were quickly isolated in order to obtain monoclonal cultures and these were characterised genetically (LSU 18S rRNA gene sequencing) as described elsewhere [21]. The date of each culture was determined according to the sediments dating from which cells were revived as described previously [19, 21]. 


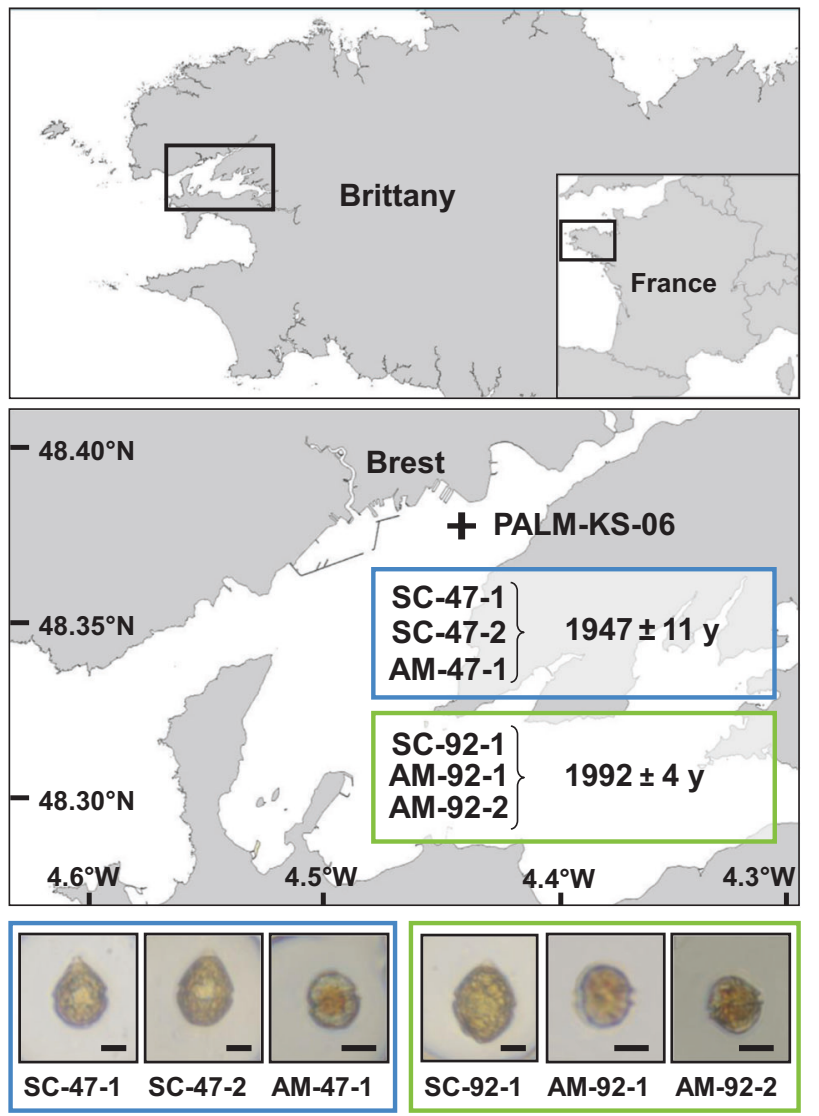

Fig. 1 Sampling area and the six dinoflagellate strains revivifed from the sediment core. The sediment core PALM-KS-06 has been sampled in the Bay of Brest, Britanny France. The bottom panel shows the six microphotographs of Scrippsiella acuminata (SC) and Alexandrium minutum (AM) strains (Scale bar $10 \mu \mathrm{m})$.

For this study, we selected six revived strains (i.e. AM47-1, AM-92-1, AM-92-2, SC-47-1, SC-47-2 and SC92-1) corresponding to dinoflagellates Alexandrium minutum (Halim) and Scrippsiella acuminata (Ehrenberg) from two selected dates $(1947 \pm 11$ and $1992 \pm 4$ years). Dinoflagellate strains were acclimated for 2 weeks into sterile flasks $(30 \mathrm{~mL})$ with $\mathrm{F} / 2$ medium in artificial seawater at $17{ }^{\circ} \mathrm{C}$ [36]. The $\mathrm{F} / 2$ medium was chosen for the presence of one single source of inorganic $\mathrm{P}$ (phosphate). This step enabled rapid growth before transfer into phosphate-deplete F/2 medium. The transfer into P-deplete medium was performed in order to obtain a cellular stress to phosphate limitation. In this study, day 0 was considered as the day when cultures started to grow on the P-depleted F/2 medium (artificial seawater). The low concentrations of phosphate measured on day 0 corresponded to the residual phosphate from the inoculum (Table 1). Cultures were exposed to a $12: 12 \mathrm{~h}$ day/night cycle at $80 \mu \mathrm{E} \mathrm{m}^{-2} \mathrm{~s}^{-1}$. Before sampling, the cultures were filtered by gravity on a $10 \mu \mathrm{m}$ nucleopore filter (Whatman) and were gently washed with fresh Pdeplete F/2 medium under laminar flow hood. This step was performed to concentrate cells in the samples, prevent bacteria contamination and ensure comparable nutrient concentrations during the APA assay on-a-chip.

\section{Lab-on-a-chip device and experimental setup}

The microfluidic chips were made of poly-(dimethylsiloxane) (Sylgard 184) from SU8-3000 negative photoresist (MicroChem Corp) moulds produced using standard softlithography procedures [37]. The surfaces of the microfluidic channels were treated using fluorosilane (Aquapel) in order to increase the hydrophobic properties of the chip. The microfluidic chip was placed on a microfluidic platform dedicated to APA measurement [34]. In this study, we added a controlled X/Y motorised platform, a microfluidic module to sort droplets containing single cells. We optimised hydrodynamic trapping by increasing the height of the channel from 30 to $60 \mu \mathrm{m}$ (Supplementary Materials Fig. 1). These three improvements allowed us to monitor a total of 100 droplets trapped in the incubation channel for each APA assay.

\section{Alkaline phosphatase activity (APA) assay on a chip}

A first series of water-in-oil droplets $(500 \mathrm{pL})$ were generated by flow-focusing the culture stream containing phytoplankton with two streams of FC40 oil containing a surfactant $(5 \% \mathrm{w} / \mathrm{w}$, Fluosurf, Emulseo). The droplets of interest were sorted according to the morphology of the cell, as previously described $[38,39]$. The droplets of interest slightly compressed in the channel were rerouted to the series of high height areas corresponding to the traps. By using the second droplet module on the chip, a train of droplets $(80 \mathrm{pL})$ was generated by flow focussing a stream containing $100 \mu \mathrm{M}$ of the ELF-97 phosphatase substrate (E6588, ThermoFisher, referred after ELF-P) with two streams of FC40 oil containing a surfactant $(5 \% \mathrm{w} / \mathrm{w})$. According to the concentrations of organic phosphate saturating the AP site of the dinoflagellate in the literature, we assumed that all the active AP sites were saturated by $100 \mu \mathrm{M}$ of ELF-P. This is a prerequisite for a meaningful comparison of APA between cells [40]. Actually, the maximal velocity rate assumed to be measured is proportional to the quantity of AP. As a consequence, our APA measurements are indicative of the enzymatic equipment of cells. By under pressurising the outlet, the small ELF-P droplets were rerouted to a series of small hydrodynamic traps and stored in contact with the droplets containing a single dinoflagellate cell. Then, the positions of droplets of interest were saved in the time-lapse sequence programme (LabVIEW). A short width pulse of voltage $(100 \mathrm{~ms}, 100 \mathrm{~V})$ is applied to the electrodes located on each side of the collection channel in order to simultaneously fuse each 
Table 1 Alkaline phosphatase activity (APA) of six dinoflagellate strains as a function of time.

\begin{tabular}{|c|c|c|c|c|c|c|c|}
\hline & $\begin{array}{l}\text { Time } \\
\text { (day) }\end{array}$ & $\begin{array}{l}{\left[\mathrm{PO}_{4}{ }^{3-}\right]} \\
(\mu \mathrm{M})\end{array}$ & $\begin{array}{l}\text { Number of } \\
\text { living cells } \\
\text { captured }\end{array}$ & $\begin{array}{l}\text { Number of } \\
\text { labelled cells }\end{array}$ & $\begin{array}{l}\text { Labelled } \\
\text { cells }(\%)\end{array}$ & 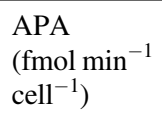 & $\begin{array}{l}\text { APA } \\
\text { SD }(\%)\end{array}$ \\
\hline \multirow[t]{4}{*}{ SC-47-1 } & 3 & 0.07 & 58 & 7 & 12 & $128 \pm 33$ & $\pm 26 \%$ \\
\hline & 4 & $<0.02$ & 135 & 14 & 10.4 & $235 \pm 60$ & $\pm 26 \%$ \\
\hline & 5 & $<0.02$ & 78 & 17 & 21.8 & $441 \pm 51$ & $\pm 12 \%$ \\
\hline & 6 & $<0.02$ & 0 & $n a$ & $n a$ & $n a$ & $n a$ \\
\hline \multirow[t]{2}{*}{ SC-47-2 } & 3 & 0.03 & 83 & 12 & 14.5 & $421 \pm 55$ & $\pm 13 \%$ \\
\hline & 4 & $<0.02$ & 0 & $n a$ & $n a$ & $n a$ & $n a$ \\
\hline \multirow[t]{4}{*}{ AM-47-1 } & 5 & 0.44 & 55 & 0 & 0 & 0 & $n a$ \\
\hline & 6 & $<0.02$ & 70 & 0 & 0 & 0 & $n a$ \\
\hline & 6.5 & $<0.02$ & 95 & 22 & 23.0 & $77 \pm 27$ & $\pm 35 \%$ \\
\hline & 7 & $<0.02$ & 100 & 0 & 0 & 0 & $n a$ \\
\hline \multirow[t]{4}{*}{ SC-92-1 } & 3 & 0.38 & 30 & 0 & 0 & 0 & $n a$ \\
\hline & 4 & $<0.02$ & 86 & 6 & 7 & $36 \pm 15$ & $\pm 42 \%$ \\
\hline & 5 & $<0.02$ & 153 & 20 & 13.1 & $241 \pm 56$ & $\pm 23 \%$ \\
\hline & 6 & $<0.02$ & 61 & 0 & 0 & 0 & $n a$ \\
\hline \multirow[t]{2}{*}{ AM-92-1 } & 6 & 0.06 & 106 & 7 & 5.7 & $16 \pm 5$ & $\pm 31 \%$ \\
\hline & 7 & $<0.02$ & 116 & 17 & 14.7 & $17 \pm 7$ & $\pm 41 \%$ \\
\hline \multirow[t]{3}{*}{ AM-92-2 } & 5 & 2.85 & 92 & 0 & 0 & 0 & $n a$ \\
\hline & 6 & 0.05 & 162 & 20 & 12.3 & $21 \pm 4$ & $\pm 19 \%$ \\
\hline & 7 & $<0.02$ & 0 & $n a$ & na & $n a$ & $n a$ \\
\hline
\end{tabular}

The average of the APA in fmol $\mathrm{min}^{-1}$ cell ${ }^{-1}$ is calculated using the living labelled cells. ( $\mathrm{na}$ ) is the absence of APA measure due to the lack of living cell found in the droplets. Number of living cells and percentage of labelled cells are also indicated in the table. droplet containing a phytoplankton with a droplet containing the ELF-P substrate. The fusion of the droplets initiates the APA assay and the images were automatically captured according to droplet locations. The APA was determined by monitoring the fluorescence signal of droplets containing a single living cell. In this study, a living cell was defined as a cell swimming in the droplet when the APA assay started. The fluorescence signal was due to the hydrolysis of ELF-P and subsequent precipitation of phenol form of ELF alcohol into a fluorescent water-insoluble form ELF-A [41]. The measurement of the fluorescent product was made according to the method described previously [34]. Blank experiments were conducted to test the APA response of strains cultivated under P-replete conditions. No ELF-A fluorescence signals were detected in the blank experiments. The presence of natural pigments, bleaching of the ELF-A and bacterial contamination were also considered in order to decrease potential bias in the fluorescence measurement (Supplementary Materials Figs. 2 and 3).

\section{Image processing systems}

In addition to the droplet sorting system based on the morphology of cells, a second image processing algorithm was developed to automatically detect the droplets and measure the fluorescence intensity in each time-lapse image (Supplementary Materials Fig. 4, [37, 42]). Because the fluorescent images were captured as a function of time, it was possible to precisely follow the variability of the fluorescence intensity of each droplet trapped in the collection channel.

\section{Phosphate measurement in the medium}

Samples for the determination of phosphate were carefully filtered through pre-combusted $\left(12 \mathrm{~h}\right.$ at $\left.480{ }^{\circ} \mathrm{C}\right) 25 \mathrm{~mm}$ Whatman GF/F. Pre-combustion of the filters is used to avoid any potential contamination. Phosphate was analysed immediately after filtration on a spectrophotometer (Shimadzu UV 160) with a $5 \mathrm{~cm}$ optical path cell. The phosphate concentration was determined according to the method of Murphy and Riley [43], with the detection limit of $0.02 \mu \mathrm{M}$.

\section{Statistical analysis}

To perform a one-way analysis of variance (ANOVA) test, we first determined all APA labelling kinetics at a singlecell level. Then, for each strain, we selected the experiment that had maximum APA values. From these maximum values, we used ANOVA to test significant differences of APA among strains of different species and ages. 


\section{Results}

\section{Automated microfluidic platform for the APA assay}

The APA has been determined on three strains of Alexandrium minutum and three strains of Scrippsiella acuminata (Fig. 1). The strains SC-47-1, SC-47-2 and AM-47-1 corresponded to the 1940's decade (1947 \pm 11 years; blue symbols in this study). The strains AM-92-1, AM-92-2 and SC-92-1 corresponded to the 1990's decade (1992 \pm 4 years; green symbols). By using the microfluidic platform, a total of 25,230 images were captured and analysed during the experiments. For each captured image, the fluorescence intensity of water-in-oil droplets containing single cells was determined as an index of APA. Six examples of the increase in fluorescence of single living dinoflagellate encapsulated in the droplets are shown in Fig. 2. The APA fluorescence curves show a typical enzyme labelling pattern with the maximum of the APA observed when the cell started to be labelled. The microphotographs showed the increase in fluorescent ELF-A product (green) on the surface of the cells as a function of time. The results showed that all strains of A. minutum had high numbers of small ELF-A spots located between the plates. All strains of $S$. acuminata also showed relatively high numbers of ELF-A spots distributed along the plate sutures, with a brighter fluorescence signal than A. minutum (Supplementary Materials Fig. 3).

\section{Temporal evolution of the APA labelling}

The simultaneous fusion of every droplet containing the phytoplankton with the droplet containing the ELF-P substrate initiated the APA assay. We found an intraclonal variability between the start of the APA assay and the observation of the first fluorescent spots at the surface of the dinoflagellates. For $S$. acuminata, we observed a fast labelling with a short lag-time $(<5 \mathrm{~s})$. In contrast, the labelling of A. minutum was obtained 10-30 min after droplet fusion. All strains induced the synthesis of APA when the cells were cultivated in phosphate-deplete $\mathrm{F} / 2$ medium (Table 1). However, the timing of induction varied between the two species. S. acuminata strains induced the synthesis of AP between 3 and 5 days since the experiment started, whereas A. minutum strains induced the synthesis of the AP between 6 and 7 days (Supplementary Materials Fig. 5). For the strains SC-47-1, SC-92-1, AM-92-1, the APA and the number of cells labelled increased as a function of time and revealed the progressive increase in phosphate stress that the cells incurred (Table 1, Fig. 3). For strains SC-47-2, AM-47-1 and AM-92-2, the APA was found only once after 3, 6.5 and 6 days, respectively, and was considered as the maximum for this study. The proportion of labelled cells ranged from $6 \%$ (AM-92-1, day 6) to $23 \%$ (AM-47-1, day 6.5), with the highest values found at the APA maximum. The results indicated that a period of 6-7 days was required to reach the maximum APA value for A. minutum, whereas 3-5 days were needed for $S$. acuminata. The day after the APA maxima, two main patterns were observed in the cultures. A first group of strain (AM-47-1; SC-92-1) had some cells still alive but not labelled. A second group of strains (SC-47-1; SC-47-2; AM-92-2) had no living cells the day after APA maxima detection.

\section{Intraclonal, intra and interspecific variability of the APA}

The higher average values of APA were measured for two strains of $S$. acuminata corresponding to 1940's period (SC-47-1: $441 \pm 51 \mathrm{fmol} \mathrm{min}^{-1}$ cell $^{-1} ; \quad$ SC-47-2: $421 \pm 55 \mathrm{fmol} \mathrm{min}^{-1} \mathrm{cell}^{-1}$ ). These values were higher than average APA values of the A. minutum strain of the same period (Table 1; Fig. 4; ANOVA, $p<0.001$ ). The average value of APA of the $S$. acuminata strain of the 1990's (241 \pm

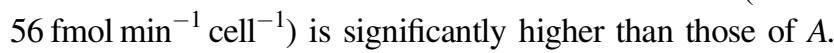
minutum strains of the same period (ANOVA, $p<0.001$ ). These two A. minutum strains had the lowest average values of APA measured among all strains and ages (AM-92-1: 17士 $7 \mathrm{fmol} \mathrm{min}{ }^{-1}$ cell $^{-1}$; AM-92-2: $21 \pm 4 \mathrm{fmol} \mathrm{min}^{-1}$ cell $^{-1}$ ). No significant differences were found between the maximum values of the APA of the strains AM-92-1 and AM-92-2 and between the strains SC-47-1 and SC-47-2. In summary, all $S$. acuminata strains had higher APA than all A. minutum strains and, for both species, strains from the 1940's had a significantly higher activity than the corresponding strains from the 1990's (ANOVA, $p<0.001$ ).

\section{Discussion}

\section{Extra/intra APA and cellular P-stress status}

We developed an integrated microfluidic platform to automatically sort droplet containing cells and perform APA assays for dinoflagellates based on fluorescence at a singlecell level. In our study, we mainly focus on external APA as an indicator of cellular P-stress status. This choice has been supported because dissolved organic phosphorus (DOP) compounds must be hydrolysed extracellularly before being assimilated as a $P$ source [44]. Moreover, the most important dissolved organic utilising enzyme is AP and is reported to be mainly located at the cell surface and its activity is mostly linked to cellular P-stress status [27]. In the literature, intracellular AP is sometimes counted for the determination of cellular P-stress status. However, there are several major issues when considering intracellular AP as a P-stress indicator. Firstly, a part of the intracellular APA has 
Fig. 2 Examples of the six strains of dinoflagellates having alkaline phosphatase activity (APA). The top panel displays the photomicrographs of the cells encapsulated in the water-in-oil droplets progressively labelled with the ELF substrate (green fluorescence). The bottom panel shows the increase in fluorescence of the cells of each strain measured by the microfluidic platform during APA assays. Scale bar $20 \mu \mathrm{m}$.
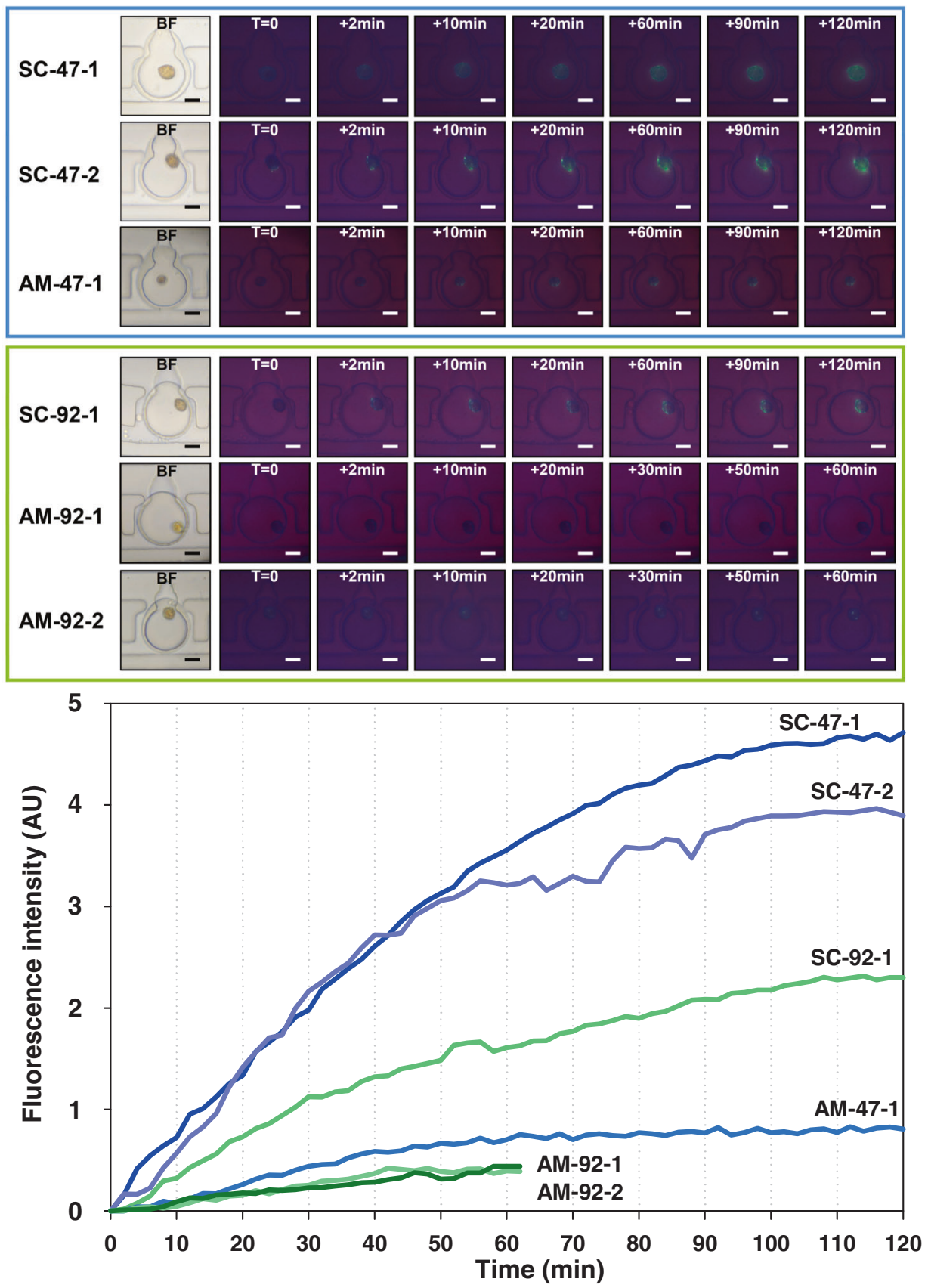

been reported to be constitutive [30]. Secondly, intracellular APA activity seems to not have an access to some external DOP compounds, because no phosphoester transporters from the cellular membrane to the intracellular contents have been discovered yet [27]. Thirdly, the internal $\mathrm{pH}$ of the cell can vary within the day, leading to a range of $\mathrm{pH}$ values more suitable for acid phosphatases that have been described as more constitutive enzymes and ensuring different cellular functions [30, 31, 44-46]. By considering the extracellular APA as a key indicator for cellular P-stress, we reported the first measurements of the regulation of the extracellular APA for two dinoflagellate species, the toxic
A. minutum and non-toxic S. acuminata. These species were obtained from germination of cysts from ancient sediments of two contrasting periods of phosphorus loadings of the Bay of Brest. Our results show significant intraspecific and inter-species APA heterogeneities and a coherent pattern of APA variability between the two tested periods of time.

\section{Temporal evolution of the APA at the single-cell level}

The microfluidic approach enabled us to enumerate APAlabelled living cells. To limit false-positive APA-labelled 

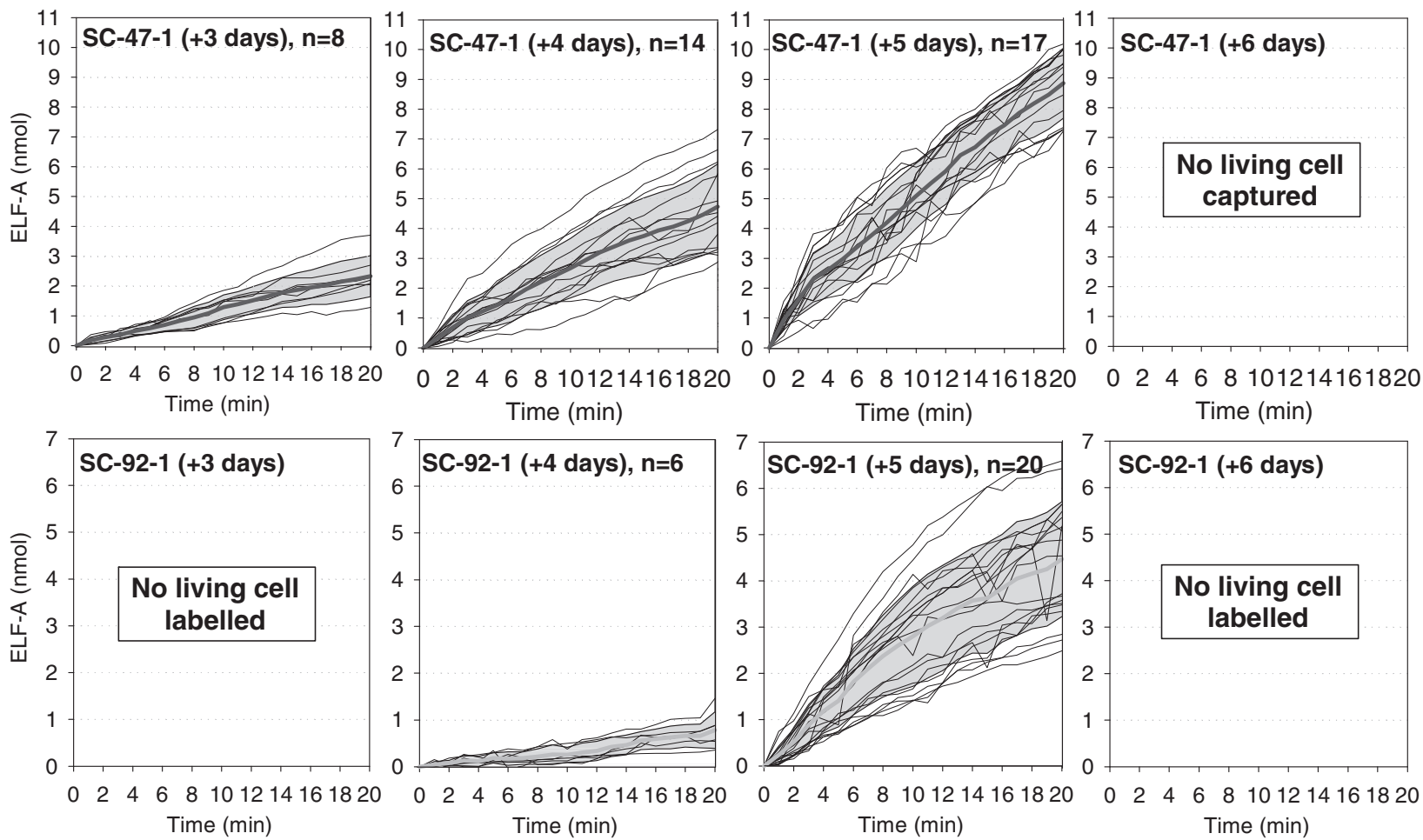

Fig. 3 Variability of the alkaline phosphatase activity (APA) for two strains of Scrippsiella acuminata (SC-47-1; SC-92-1) as a function of time. The hairlines show the APA of each cell which induces alkaline phosphatase (AP) synthesis, the thick lines are the

average of APA and shade areas are the standard deviations. 'No living cell captured' means that no living cell was trapped in the microfluidic chip. 'No living cell labelled' means that all living cells captured in the microfluidic did not induce AP synthesis.
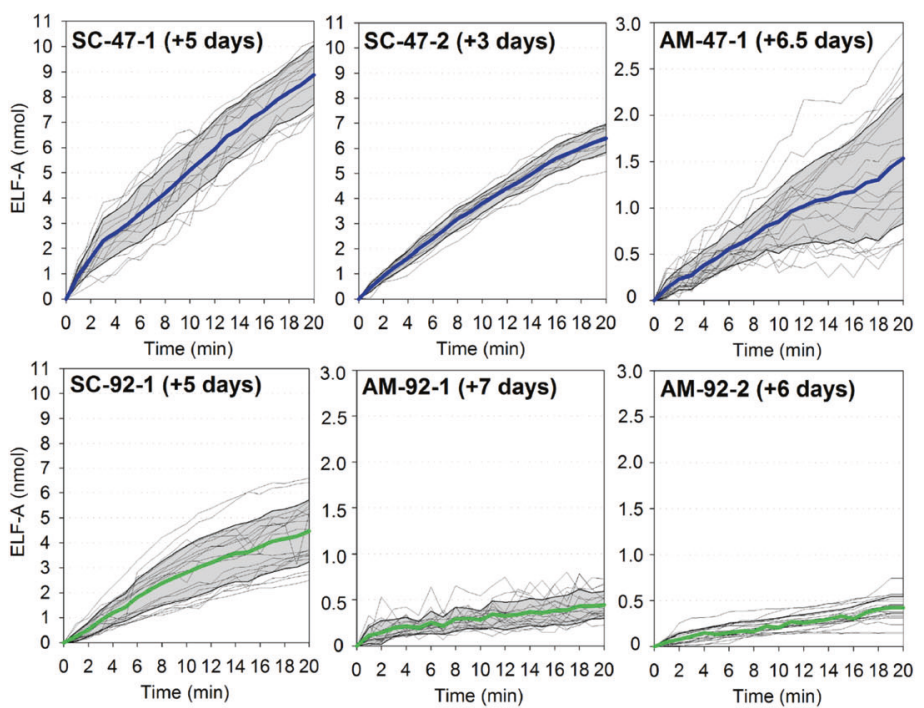

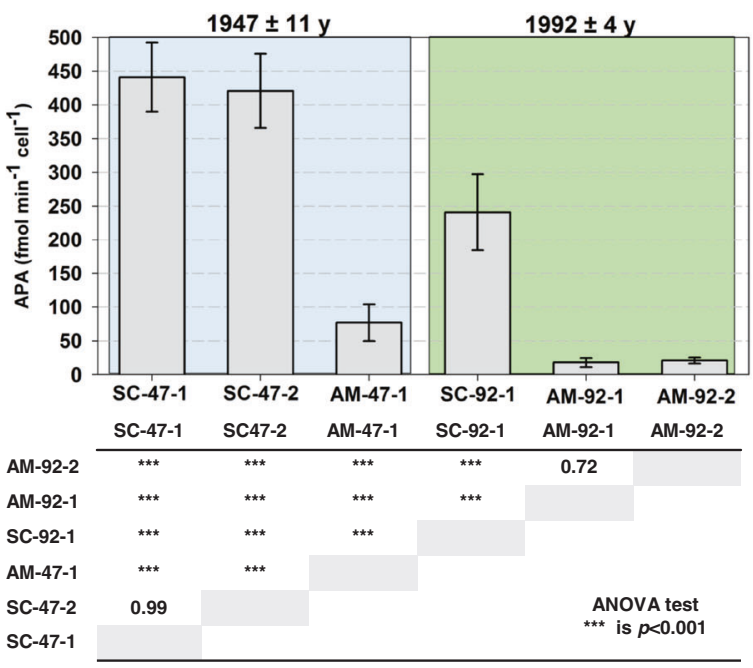

Fig. 4 Difference in the maximum alkaline phosphatase activity (APA) of the Scrippsiella acuminata (SC) and Alexandrium minutum (AM) strains. The left panels show the increase of the fluorescent product of the enzymatic assay (ELF-A) as a function of time. Each hairline shows the ELF-A measured of a single cell. The thick lines are the average of the ELF-A and shade area is the standard deviation of

the ELF-A measured during the experiment. The data collected within the $20 \mathrm{~min}$ are used to determine the maximum of the APA. The corresponding APA data are plotted on the right panel. Using all the data set, the one-way ANOVA test was performed to compare APA among the different strains. 
cells, we considered the swimming capability of the phytoplankton as a screening process for the detection of cell living status. This step allowed us to discard cysts and dead cells that have been reported to overestimate APA [47]. Because ELF substrate did not enter through a compromised cellular membrane and only living dinoflagellates marked with fluorescent ELF-A spots were counted as a positively labelled cell, the microfluidic approach enabled us to improve the measurement accuracy of the APA [48]. Furthermore, cells were not fixed with ethanol, paraformaldehyde or $\mathrm{HgCl}_{2}$, which are fixatives commonly reported to permeabilize cell membranes and affect cellular integrity [49-51]. The permeabilization of the cell membrane overestimates the proportion of positive cells because substrates can enter through the cell and label intracellular enzyme activity. Indeed, we obtained lower proportions of labelled cells in P-depleted samples (6-22\%) than reported by other studies testing dinoflagellate fixed cells (e.g. $\sim 79 \%$ for $A$. catenella and $A$. tamarense [52]; $68 \%$ for Alexandrium spp., $82-84 \%$ for Protoperidinium spp. and Karenia mikimotoi [29]; 50-90\% for S. acuminata (there named S. trochoidea) [53]). Yet, we consider that the number of mobile labelled cells is sufficient for identifying significant intra and interspecific variabilities among strains and species, and to study this variability across strains of different ages. A higher number of cells would likely decrease the standard deviation but not significantly change our conclusions.

AP synthesis is commonly reported to be induced by phytoplankton during phosphorus stress [54]. However, the regulation of AP synthesis appears not to be ubiquitous among phytoplankton species because several species, including the dinoflagellate Alexandrium catenella (named as A. fundyense), were observed to constantly express variation in AP whatever the P-content in the media $[50,55,56]$. Moreover, due to the lack of clear ecological relationships between APA and phosphate concentrations, Flynn et al. reported that APA was not a reliable indicator of the P-status for the species A. minutum [57]. In our study, the absence of labelled cells at the beginning of monitoring and the progressive increase in number of labelled cells and APA through time suggested that almost all extracellular AP enzymes were not constitutive but were induced under P-deplete conditions. Moreover, our results suggest that APA is directly regulated by the cells through time. The temporal variability of APA observed here highlights the need for time series monitoring of enzyme regulation over several days in order to measure and compare the highest APA as possible among strains. Two different dynamics of APA increase have been found. First, a progressive increase of APA has been observed at the timescale of several days in $S$. acuminata strains (2-5 days). Second, a fast regulation of APA ( $<1$ day) was found for the A. minutum strains AM47-1 and AM-92-2. This fast regulation of the APA suggests that, despite our sampling efforts, the maximum values of APA determined in this study were probably not the highest that the strains can reach. Because the sorting and labelling steps in our microfluidic platform took $\sim 3 \mathrm{~h}$, further improvements of the APA assay and microfluidic procedures may be required for studying fast regulation of APA at shorter timescales.

No living cells of AM-47-1 and SC-92-1 strains were labelled the day after a maximum of APA. Although the repression of APA can take 3 days for some dinoflagellate species, fast repression of APA has also been observed in on-a-field experiments and in cultures growing under P-deplete conditions [58-60]. The fast repression of AP synthesis observed in this study tends to confirm previous analyses showing a decrease in APA after 4-5 days of incubation, concomitant with the presence of APA in the dissolved fraction $[34,56,58]$. To explain such a quick repression of the AP synthesis while dissolved inorganic phosphate concentrations are still under the detection limit in the culture medium, we previously suggested that freeAP enzyme released from living cells or cell lysates in the dissolved fraction of the culture allowed new P-availability for the cell and consequently repressed intracellular AP synthesis [34]. The potential effect of phosphate released by free-AP enzymes in the medium on the cellular repression of AP synthesis has not been tested in this study. However, according to our culture conditions, the lyses of P-limited cells might have released free-AP enzyme in the batch culture and might have caused fast repression of AP synthesis, especially given that free-AP enzymes have been reported to have a long lifetime ( $>2$ weeks) in laboratoryincubated environmental samples [61].

\section{Intraclonal and Intraspecific variabilities of the APA}

Our results revealed a particularly high intraclonal variability of the APA (SD: from $\pm 12 \%$ to $\pm 42 \%$, Table 1 ). The important variability of APA at the intraclonal level adds the evidence for high phenotypic heterogeneity of cells growing under the same environmental conditions. This result helps to confirm a recent single-cell labelling study that reported order of magnitude differences between the lowest and highest APA cell measurements for cultivation in phosphate-limited conditions [34]. High metabolic heterogeneity was also observed in nitrate and nitrogen uptakes and was suggested to be an investment of some cells in advance of nutrient availability changes [8, 62]. To cope with fluctuating nutrient conditions, some cells develop a set of enzymes with different affinities to the substrate. For example, Dyhrman and Palenik suggested that the haptophyte Emiliania huxleyi has a set of cell-surface AP enzymes with different substrate affinities [63]. By using AP enzymes with high or low affinities, Emiliania huxleyi 
cells show different kinetics as a function of the $\mathrm{P}$ concentration in the environment. Due to the high phenotypic heterogeneity of APA, and the relatively low number of positive cells observed in this study, identification of different kinetic patterns of the APA is difficult. Indeed, observations of ELF-A spots with different fluorescent intensities between the armour plates on the same cell can be the result of a locally higher spatial density of enzymes or the presences of enzymes with different affinities, as reported for the species Emiliania huxleyi [62].

Although the intraclonal APA heterogeneity found here was high, APA kinetic differences between the two pairs of strains from the same species and same age cannot be discriminated significantly (i.e. SC-47-1 and SC-47-2; AM92-1 and AM-92-2, Fig. 4). This result indicates that APA variability among strains of one species is hidden by the high intraclonal heterogeneity of APA within a strain. The enzymatic responses of the two pairs of strains to phosphate stress are particularly homogeneous and suggest that the strains of a species of same age had a same enzymatic answer to a P-limited environment. Therefore, among the population of dinoflagellates tested in this study and living in the same environment, the variation of APA appears to be more linked to the phenotypic heterogeneity than the intraspecies variability.

\section{Interspecific variability of the APA}

The range of the APA measured by cell in the present study (16-441 fmol $\mathrm{min}^{-1} \mathrm{cell}^{-1}$; Table 1) was in agreement with APA measured in other dinoflagellate species using different protocols (e.g. 160-830 fmol $\mathrm{min}^{-1} \mathrm{cell}^{-1}$ for $A$. tamarense; $12.5 \mathrm{fmol} \mathrm{cell}^{-1} \mathrm{~min}^{-1}$ for A catenella) [64, 65]. In this range, a constantly higher APA was observed for $S$. acuminata compared to A. minutum strains. This difference of level of activity, associated with a rapid trigger of the APA regulation found in $S$. acuminata, suggests that Prequirement was higher for $S$. acuminata than for $A$. minutum. The long delay time to trigger the APA in A. minutum cultures could be related to the capacity of this species to store phosphate in the cell and a lower P-requirement needed for growth. The intracellular phosphorus content is well known to be a factor able to more directly control the APA than external phosphate concentration [66-68]. To estimate the P-storage capacities of a species, the "luxury coefficient" has been commonly used in the literature since its original publication [69]. This indicator is the ratio of the P-content of cell cultivated in P-replete conditions to the $\mathrm{P}$-content of cell living in P-deplete conditions. Literature records tend to support the first hypothesis, stating a larger storage capacity of $A$. minutum in comparison with $S$. acuminata. Indeed, a luxury coefficient of 8.1 can be determined for $A$. minutum from the compilation of different studies conducted on the same strain [70-72], whereas the ratio reported of $S$. acuminata ranges from 1.4 to 2.9 [73-75]. Therefore, abilities of A. minutum to store $\mathrm{P}$ in the intracellular phosphate pool may help this species to maintain the functional cell machinery even when phosphate becomes depleted in the medium and may delay or limit the synthesis of AP under P-stress. The high storage capacity of $A$. minutum associated with a low P-requirement may also result in difficulty to observe APA under low phosphate concentration in on-a-field studies [54].

\section{Ecological implications of APA variabilities}

Few studies addressed the effect of the cellular metabolism heterogeneity on the dynamics of phytoplankton population [76-78]. However, the emergence of single-cell methods brings growing evidence that among a population composed of theoretically "genetically identical" cells, heterogeneity of metabolism can modify the cell distribution and resilience [6, 79-81]. Our results have shown that, for a same species, the average values at maximum APA in the old strains $(1947 \pm 11$ years) are significantly higher than the activities of more recent ones (1992 \pm 4 years). This interage variability of the APA observed suggests that two different dinoflagellate species have co-adapted to the changing environmental conditions occurred in the Bay of Brest at half-century timescale. However, it remains difficult to precisely link the regulation of APA and the hydrological parameters, such as phosphate concentrations and nutrient stoichiometry measured in the Bay of Brest. Indeed, nutrient concentrations were not routinely measured at the end of the 1940's and one of the first standard protocols for the measurement of phosphate in marine water has only been published by 1962 [44]. Despite these technical limitations, several hydrological patterns can be reconstructed based of the historical measurements (Supplementary Materials, supplementary Materials Fig. 6). Although other environmental parameters, such as light, could limit the growth of dinoflagellates in turbid coastal environment or during winter, the historical trends suggest that, within all nutrients, phosphate appeared to be a potential limiting factor for phytoplankton development since the early 1990's (Supplementary Materials [80]). This limitation is mainly linked to the higher increase of nitrate concentrations than phosphate in rivers from the end of 1940's to the 1990's decade and the consequent dystrophic unbalancing of N/P ratios in the environment. Strains that lived in 1990's, in potentially more important P-limited conditions than 1940's, would be expected to show high APAs. Surprisingly, even if the N/P ratio ranged from 170 to 426 in the early 1990's decade, the APA assays performed on A. minutum and S. acuminata strains indicated, for both species, an opposite trend, showing lower APA level for 1990's decade strains. 
Given that the progressive P limitation of phytoplankton cannot be demonstrated during the 1940-90 period because of the absence of nutrient data, we can advance two different hypotheses to explain low APAs observed for recent strains. A first hypothesis would be that dinoflagellate populations have not been P-limited during the 1940-90 period. The regular high $\mathrm{P}$ riverine concentrations and sediment inputs associated with the storage ability of some species could have ensured $\mathrm{P}$ needs of both dinoflagellate species. Therefore, these populations were not selected across time on the efficiency to use $\mathrm{P}$ and the increase of the APA because the P inputs were sufficient for living cells. This hypothesis is plausible if phosphate concentrations have actually increased from the 1940's to the 1990's in parallel with nitrate concentrations and the P-storage ability did not significantly change at the half-century timescale. A second hypothesis supposes a lower concentration of $\mathrm{P}$ in the environment during the 1940-90 period, to which some dinoflagellate sub-populations had progressively adapted. In this scenario, dinoflagellates of the 1990's period would have optimized the utilisation of intracellular stock of $\mathrm{P}$, relying on this storage when limiting conditions occurred in the environment. Being adapted to lower $\mathrm{P}$ concentrations in the environment, dinoflagellates of the 1990's decade would have lower APA because the P cell requirement would be ensured by intracellular pool storage. This hypothesis is consistent with the high phenotopic plasticity of phytoplankton to adapt its cellular requirement under $\mathrm{P}$ starvation [82, 83]. Additional experiments including a higher number of strains are required to better understand the ecological importance of the APA in phosphate limiting conditions, including modern/actual strains from this same ecosystem. A major issue would be to understand if the energy cost for a cell to express and maintain the APA constitutes a significant advantage over other survival strategies at a half-century timescale. A concluding evidence of our observations is however that dinoflagellates can modify some physiological constants in order to survive in a changing environment [84].

\section{Conclusions}

We determined the regulation of the APA at the single-cell level for two dinoflagellate species, A. minutum and $S$. acuminata, which were revived from ancient sediment core and cultivated under P-deplete conditions. The inter-species comparison of the APA indicated that $S$. acuminata had a significantly higher APA than A. minutum strains. This inter-species variability of the APA may result from a relatively high storage capacity of phosphorus reported in $A$. minutum. The intraspecific comparison of strains with different ages revealed that recent strains $(1992 \pm 4$ years $)$ had a significantly lower APA than the old strains $(1947 \pm 11$ years). Although genotypic analysis should be conducted to confirm our observations, our results suggested that the significant modification in the expression of the APA can take place at the half-century timescale in order to cope with the $\mathrm{P}$ concentration modifications in the environment. Adaptation to variations in $\mathrm{P}$ concentrations had probably contributed to generate similar evolution pattern in APA of these dinoflagellate strains. The microfluidic technology demonstrated here provides an efficient approach for exploring and measuring physiological changes at the single-cell level to modifications of the nutrient conditions. These results highlight the need to consider the plasticity of cells in ecological models, especially if the phytoplankton species can modify its own physiology faster than the longterm projection of the climate change scenario.

Acknowledgements We thank the Syndicat de bassin d'Elorn for providing the historical data of nitrate and phosphate concentrations. MG, JCB and YDA acknowledge financial support of a Marie-Curie Individual Fellowships (IF) MAPAPAIMA (797007). JCB acknowledges the financial support of the Region Nouvelle Aquitaine and from the French state in the frame of the 'investment for the future' (Programme IdEx Bordeaux, ANR-10-IDEX-03-02). Revived cultures and culture experiments were carried out in the frame of the project PALMIRA part of the project PALMIRA (Palaeoecology of Alexandrium minutum dans la Rade de Brest-Marché n²017-90292) financed by the Région Brittany. We are grateful to all members of the crew of the N/O Thalia ship of Ifremer for providing technical expertise in sediment core collection and to Emulseo for providing the surfactant used in this study. We thank Prof. Josh D. Neufeld and anonymous reviewers for their valuable comments and insights that considerably helped to improve the manuscript.

Author contributions MG, JCB and RS conceived and designed the study (MG, JCB microfluidics; MG, RS microbiology). Experiments were performed by MG (APA experiments, microfluidics), CL (phosphate concentrations measurements) and ML (cultivation and preparation of cells) under the supervision of RS and JCB. MG, LB and TB contributed analytical tools (MG, LB microfluidic platform and instrumentation; MG, TB microfluidic chips, MG image processing). MG, CL, CJ, YDA and JCB contributed to data analysis. MG, JCB and RS wrote the manuscript with contributions from all authors.

\section{Compliance with ethical standards}

Conflict of interest JCB is a co-founder of Emulseo whose surfactant formulation was used in this study.

Publisher's note Springer Nature remains neutral with regard to jurisdictional claims in published maps and institutional affiliations.

\section{References}

1. Gobler CJ, Doherty OM, Hattenrath-Lehmann TK, Griffith AW, Kang R, Litaker W. Ocean warming has expanded niche of toxic algae. Proc Natl Acad Sci USA. 2017;114:4975-80.

2. Olivieri ET. Colonization, adaptations and temporal changes in diversity and biomass of a phytoplankton community in upwelled 
water off the Cape Peninsula, South Africa, in December 1979. South Afr J Mar Sci. 1983;1:77-109.

3. Irwin AJ, Zoe V, Finkel ZV, Müller-Karger FE, Troccoli, Ghinaglia L. Phytoplankton adapt to changing ocean environment. Proc Natl Acad Sci USA. 2015;112:5762-6.

4. Chivers W, Walne A, Hays G. Mismatch between marine plankton range movements and the velocity of climate change. Nat Commun. 2017;8:14434.

5. Gisselson L, Granéli E, Pallon J. Variation in cellular nutrient status within a population of Dinophysis norvegica (Dinophyceae) growing in situ: single - cell elemental analysis by use of a nuclear microprobe. Limnol Oceanogr. 2001;5. https://doi.org/10.4319/lo. 2001.46.5.1237.

6. Ackermann M. A functional perspective on phenotypic heterogeneity in microorganisms. Nat Rev Microbiol. 2015;13:497-508. https://doi.org/10.1038/nrmicro3491.

7. Núñez-Milland DR, Baines SB, Vogt S, Twining BS. Quantification of phosphorus in single cells using synchrotron X-ray fluorescence. J Synchrotron Radiat. 2010;17:560-6.

8. Berthelot H, Duhamel S, L'Helguen S, Maguer JF, Wang S, Cetinić I, et al. NanoSIMS single cell analyses reveal the contrasting nitrogen sources for small phytoplankton. ISME J. 2019;13:651-62. https://doi.org/10.1038/s41396-018-0285-8.

9. Štrojsová A, Vrba J. Short-term variation in extracellular phosphatase activity: possible limitations for diagnosis of nutrient status in particular algal populations. Aquat Ecol. 2009;43:19-25.

10. O'Donnell DR, Hamman CR, Johnson EC, Kremer CT, Klausmeier CA, Litchman E. Rapid thermal adaptation in a marine diatom reveals constraints and trade-offs. Glob Change Biol. 2018;24:4554-65.

11. Jin P, Agustí S. Fast adaptation of tropical diatoms to increased warming with trade-offs. Sci Rep. 2018;8:17771. https://doi.org/ 10.1038/s41598-018-36091-y.

12. Thomas CD, Cameron A, Green RE, Bakkenes M, Beaumont LJ, Collingham YC, et al. Extinction risk from climate change. Nature. 2004;427:145-8.

13. Urban MC. Accelerating extinction risk from climate change. Science. 2015;348:571-3.

14. Kottuparambil S, Jin P, Agusti S. Adaptation of Red Sea Phytoplankton to experimental warming increases their tolerance to toxic metal exposure. Front Environ Sci. 2019;7. https://doi.org/ 10.3389/fenvs.2019.00125.

15. Flores-Moya A, Costas E, Lopez-Rodas V. Roles of adaptation, chance and history in the evolution of the dinoflagellate Prorocentrum triestinum. Naturwissenschaften. 2008:95:697-703.

16. Flores-Moya A, Rouco M, García-Sánchez MJ, García-Balboa C, González R, Costas E, et al. Effects of adaptation, chance, and history on the evolution of the toxic dinoflagellate Alexandrium minutum under selection of increased temperature and acidification. Ecol Evol. 2012;2:1251-9. https://doi.org/10.1002/ece3.198.

17. Martiny AC, Ustick LA, Garcia C, Lomas MW. Genomic adaptation of marine phytoplankton populations regulates phosphate uptake. Limnol Oceanogr. 2019. https://doi.org/10.1002/ lno.11252.

18. Ribeiro S, Berge T, Lundholm N, Andersen TJ, Abrantes F, Ellegaard M. Phytoplankton growth after a century of dormancy illuminates past resilience to catastrophic darkness. Nat Commun. 2011;2:311

19. Delebecq G, Schmidt S, Ehrhold A, Latimier M, Siano R. Revival of ancient marine dinoflagellates using molecular biostimulation. J Phycol. 2020;56:1077-89.

20. Ribeiro S, Berge T, Lundholm N, Ellegaard M. Hundred years of environmental change and phytoplankton ecophysiological variability archived in coastal sediments. PLoS ONE. 2013;8: e61184.
21. Klouch KZ, Schmidt S, Andrieux Loyer F, Le Gac M, HervioHeath D, Qui-Minet ZN, et al. Historical records from dated sediment cores reveal the multidecadal dynamic of the toxic dinoflagellate Alexandrium minutum in the Bay of Brest (France). FEMS Microbiol Ecol. 2016;92:1-16.

22. Lundholm N, Ribeiro S, Godhe A, Rostgaard Nielsen L, Ellegaard M. Exploring the impact of multidecadal environmental changes on the population genetic structure of a marine primary producer. Ecol Evol. 2017;7:3132-42.

23. Moore CM, Mills MM, Arrigo KR, Berman-Frank I, Bopp L, Boyd PW, et al. Processes and patterns of oceanic nutrient limitation. Nat Geosci. 2013;6:701-10.

24. Labry C, Herbland A, Delmas D. The role of phosphorus on planktonic production of the Gironde plume waters in the Bay of Biscay. J Plankt Res. 2002;24:97-117.

25. Girault M, Arakawa H, Hashihama F. Phosphorus stress of microphytoplankton community in the western subtropical North Pacific. J Plankt Res. 2013;35:146-57.

26. Ramos JBE, Schulz KG, Voss M, Narciso Á, Müller MN, Reis $\mathrm{FV}$, et al. Nutrient-specific responses of a phytoplankton community: a case study of the North Atlantic Gyre. Azores J Plankt Res. 2017;39:744-61.

27. Lin S, Litaker RW, Sunda WG. Phosphorus physiological ecology and molecular mechanisms in marine phytoplankton. J Phycol. 2016;52:10-36.

28. Lomas MW, Swain A, Shelton R, Ammerman JW. Taxonomic variability of phosphorus stress in Sargasso Sea phytoplankton. Limnol Oceanogr. 2004;49:2303-10.

29. Wang D, Huang B, Liu X, Liu G, Wang H. Seasonal variations of phytoplankton phosphorus stress in the Yellow Sea Cold Water Mass. Acta Oceano Sin. 2014;33:124-35.

30. Cembella AD, Antia NJ, Harrison PJ. The utilization of inorganic and organic phosphorous compounds as nutrients by eukaryotic microalgae: a multidisciplinary perspective: part I. CRC Crit Rev Microbiol. 1984;10:317-91.

31. Cooper A, Bowen ID, Lloyd D. The properties and subcellular localization of acid phosphatases in the colourless alga Polytomella caeca. J Cell Sci. 1974;15:605-18.

32. Duhamel S, Björkman KM, Van Wambeke F, Moutin T, Karl DM. Characterization of alkaline phosphatase activity in the North and South Pacific Subtropical Gyres: Implications for phosphorus cycling. Limnol Oceanogr. 2011;56:1244-54.

33. Kang W, Wang ZH, Liu L, Guo X. Alkaline phosphatase activity in the phosphorus-limited southern Chinese coastal waters. J Environ Sci. 2019;86:38-49.

34. Girault M, Beneyton T, Pekin D, Buisson L, Bichon S, Charbonnier $\mathrm{C}$, et al. High-content screening of plankton alkaline phosphatase activity in microfluidics. Anal Chem. 2018;90:4174-81. https://doi. org/10.1021/acs.analchem.8b00234.

35. Anderson RA, Berges RA, Harrison PJ, Watanabe MM. Appendix A - recipes for freshwater and seawater media; enriched natural seawater media. In Andersen RA, editor. Algal culturing techniques. San Diego, USA: Academic; 2005. p. 429-538.

36. Guillard RL, Ryther JH. Studies of marine planktonic diatoms. I. Cyclotella nana Hustedt, and Detonula confervacea (cleve) Gran. Can J Microbiol. 1962;8:229-39.

37. Duffy DC, McDonald JC, Schueller OJ, Whitesides GM. Rapid prototyping of microfluidic systems in poly(dimethylsiloxane). Anal Chem. 1998;70:4974-84.

38. Girault M, Hattori A, Kim H, Arakawa H, Matsuura K, Odaka M, et al. An on-chip imaging droplet-sorting system: a real-time shape recognition method to screen target cells in droplets with single cell resolution. Sci Rep. 2017;7:40072. https://doi.org/10.1038/srep40072.

39. Girault M, Odaka M, Kim H, Matsuura K, Terazono H, Yasuda K. Particle recognition in microfluidic applications using a template 
matching algorithm. JPN J Appl Phys. 2016;55. https://doi.org/10. 7567/JJAP.55.06GN05.

40. Urvoy M, Labry C, Delmas D, Creac'h L, L'Helguen S. Microbial enzymatic assays in environmental water samples: impact of Inner Filter Effect and substrate concentrations. Limnol Oceanogr Methods. 2020;18:728-38.

41. Huang Z, Terpetschnig E, You W, Haugland RP. 2-(2'phosphoryloxyphenyl)-4-(3H)-quinazolinone derivatives as fluorogenic precipitating substrates of phosphatases. Anal Biochem. 1992;207:32-39.

42. Girault M, Hattori A, Kim H, Matsuura K, Odaka M, Terazono H et al. Algorithm for the precise detection of single and cluster cells in microfluidic applications. Cytom Part A. 2016. https://doi.org/ 10.1002/cyto.a.22825.

43. Murphy J, Riley JP. A modified single solution method for the determination of phosphate in natural waters. Anal Chim Acta. 1962;27:31-36.

44. Hoppe HG. Phosphatase activity in the sea. Hydrobiologia. 2003; 493:187-200.

45. Golda-VanEeckhoutte RL, Roof LT, Needoba JA, Peterson DT. Determination of intracellular $\mathrm{pH}$ in phytoplankton using the fluorescent probe, SNARF, with detection by fluorescence spectroscopy. J Microbiol Methods. 2018;152:109-18.

46. Kruskopf MM, Du Plessis S. Induction of both acid and alkaline phosphatase activity in two green-algae (chlorophyceae) in low $\mathrm{N}$ and $\mathrm{P}$ concentrations. Hydrobiologia. 2004;513:59-70.

47. Štrojsová A, Vrba J, Nedoma J, Komárková J, Znachor P. Seasonal study of extracellular phosphatase expression in the phytoplankton of a eutrophic reservoir. Eur J Phycol. 2003;38:295-306.

48. Skelton HM, Parrow MW, Burkholder JM. Phosphatase activity in the heterotrophic dinoflagellate Pfiesteria shumwayae. Harmful Algae 2006;5:395-406.

49. Nedoma J, Štrojsová A, Vrba J, Komárková J, Simek K. Extracellular phosphatase activity of natural plankton studied with ELF97 phosphate: fluorescence quantification and labelling kinetics. Environ Microbiol. 2003;5:462-72.

50. Young EB, Tucker RC, Pansch LA. Alkaline phosphatase in freshwater Cladophora-epiphyte assemblages: regulation in response to phosphorus supply and localization. J Phycol. 2010; 46:93-101.

51. Díaz-de-Quijano D, Felip M. A comparative study of fluorescencelabelled enzyme activity methods for assaying phosphatase activity in phytoplankton. A possible bias in the enzymatic pathway estimations. J Micro Meth. 2011;86:104-7.

52. Ou L, Huang B, Lin L, Hong H, Zhang F, Chen Z. Phosphorus stress of phytoplankton in the Taiwan Strait determined by bulk and single-cell alkaline phosphatase activity assays. Mar Ecol Prog Ser. 2006;327:95-106.

53. Huang B, Ou L, Wang X, Huo W, Li R, Hong H, et al. Alkaline phosphatase activity of phytoplankton in East China Sea coastal waters with frequent harmful algal bloom occurrences. Aquat Micro Ecol. 2007;49:195-206.

54. Ivančić I, Pfannkuchen M, Godrijan J, Djakovac T, Pfannkuchen DM, Korlević $\mathrm{M}$, et al. Alkaline phosphatase activity related to phosphorus stress of microphytoplankton in different trophic conditions. Prog Oceanogr. 2016;146:175-86.

55. González-Gil S, Keafer B, Jovine JMR, Aguileral A, Lu S, Anderson DM. Detection and quantification of alkaline phosphatase in single cells of phosphorus-starved marine phytoplankton. Mar Ecol Prog Ser. 1998;164:21-35.

56. Dyhrman ST, Ruttenberg KC. Presence and regulation of alkaline phosphatase activity in eukaryotic phytoplankton from the coastal ocean: Implications for dissolved organic phosphorus remineralization. Limnol Oceanogr. 2006;51. https://doi.org/10.4319/lo. 2006.51.3.1381.
57. Flynn K, Jones KJ, Flynn KJ. Comparisons among species of Alexandrium (Dinophyceae) grown in nitrogen- or phosphoruslimiting batch culture. Mar Biol. 1996;126:9-18.

58. Perry MJ. Alkaline phosphatase activity in subtropical Central North Pacific waters using a sensitive fluorometric method. Mar Biol. 1972;15:113-9.

59. Dyhrman ST, Palenik B. Phosphate stress in cultures and field populations of the dinoflagellate prorocentrum minimum detected by a single-cell alkaline phosphatase assay. Appl Environ Microbiol. 1999;65:3205-12.

60. Mulholland MR, Floge S, Carpenter EJ, Capone DG. Phosphorus dynamics in cultures and natural populations of Trichodesmium spp. Mar Ecol Prog Ser. 2002;239:45-55.

61. Thomson B, Wenley J, Currie K, Hepburn C, Herndl GJ, Baltar F. Resolving the paradox: Continuous cell-free alkaline phosphatase activity despite high phosphate concentrations. Mar Chem. 2019; 214:103671.

62. Foster RA, Sztejrenszus S, Kuypers MMM. Measuring carbon and $\mathrm{N} 2$ fixation in field populations of colonial and free-living unicellular cyanobacteria using nanometer-scale secondary ion mass spectrometry. J Phycol. 2013;49:502-16.

63. Dyhrman ST, Palenik B. Characterization of ectoenzyme activity and phosphate-regulated proteins in the coccolithophorid Emiliania huxleyi. J Plankton Res. 2003;25:1215-25.

64. Oh SJ, Yamammoto T, Kataoka Y, Matsuda O, Matsuyama Y, Katani Y. Utilization of dissolved organic phosphorus by the two toxic dinoflagellates, Alexandrium tamarense and Gymnodinium catenatum (Dinophyceae). Fish Sci. 2002;68:416-24.

65. Jauzein C, Labry C, Youenou A, Quéré J, Delmas D, Collos Y. Growth and phosphorus uptake by the toxic dinoflagellate Alexandrium catenella (Dinophycea) in response to phosphate limitation. J Phycol. 2010;46:926-36.

66. Elgavish A, Halmann M, Berman T. A comparative study of phosphorus utilization and storage in batch cultures of Peridinium cinctum, Pediastrum duplex and Cosmarium sp., from Lake Kinneret (Israel). Phycologia. 1982;21:47-54.

67. Flynn K, Franco JM, Fernandez P, Reguera B, Zapata M, Wood G, et al. Changes in toxin content, biomass and pigments of the dinoflagellate Alexandrium minutum during nitrogen refeeding and growth into nitrogen or phosphorus stress. Mar Ecol Prog Ser. 1994;111:99-109.

68. Ou L, Wang D, Huang B, Hong H, Qi Y, Lu S. Comparative study of phosphorus strategies of three typical harmful algae in Chinese coastal waters. J Plankton Res. 2008;30:1007-17.

69. Droop MR. The nutrient status of algal cells in continuous culture. J Mar Biol Ass UK. 1974;54:825-55.

70. Bechemin C, Grzebyk D, Hachame F, Hummert C, Maestrini S. Effect of different nitrogen/phosphorus nutrient ratios on the toxin content in Alexandrium minutum. Aquat Micro Ecol. 1990;20: $157-65$.

71. Labry C, Erard-Le Denn E, Chapelle A, Fauchot J, Youenou A, Crassous MP, et al. Competition for phosphorus between two dinoflagellates: A toxic Alexandrium minutum and a non-toxic Heterocapsa triquetra. J Exp Mar Biol Ecol. 2008;358:124-35.

72. Chapelle A, Labry C, Sourisseau M, Lebreton C, Youenou A, Crassous MP. Alexandrium minutum growth controlled by phosphorus An applied model. J Mar Syst. 2010;83:181-91.

73. Sakshaug E, Granéli E, Elbrächter M, Kayser H. Chemical composition and alkaline phosphatase activity of nutrient-saturated and P-deficient cells of four marine dinoflagellates. J Exp Mar Biol Ecol. 1984;11:241-54.

74. Lirdwitayaprasit T, Okaichi T, Montani S, Ochi T, Anderson DM. Changes in cell chemical con position during the life cycle of Scrippsiella trochoidea (Dinophyceae). J Phycol. 1990;26: 299-306. 
75. Qi H, Wang J, Wang Z. A comparative study of maximal quantum yield of photosystem II to determine nitrogen and phosphorus limitation on two marine algae. J Sea Res. 2013;80:1-11.

76. Simon N, Cras AL, Foulon E, Lemée R. Diversity and evolution of marine phytoplankton. C R Biol. 2009;332:159-70.

77. Rengefors K, Kremp A, Reusch TBH, Wood AM. Genetic diversity and evolution in eukaryotic phytoplankton: revelations from population genetic studies. J Plankton Res. 2017;39:165-79.

78. Bendif EM, Nevado B, Wong ELY, Wong EL, Hagino K, Probert I, et al. Repeated species radiations in the recent evolution of the key marine phytoplankton lineage Gephyrocapsa. Nat Commun. 2019;10:4234.

79. Thornton DCO. Individuals clones or groups? Phytoplankton behaviour and units of selection. Ethol Ecol Evol. 2002;14:165-73.

80. Gerecht A, Romano G, Lanora A, d'Ippolito G, Cutignano A, Fontana A. Plasticity of Oxylipin metabolism among clones of the marine diatom Skeletonema marinoi (Bacillariophyceae). J Phycol. 2011;47:1050-6.

81. Lim PT, Leaw CP, Usup G, Kobiyama A, Koike K, Ogata T. Effects of light and temperature on growth, nitrate uptake, and toxin production of two tropical dinoflagellates: Alexandrium tamiyavanichii and Alexandrium minutum (Dinophyceae). J Phycol. 2006; 42:786-99.

82. Van Mooy BA, Fredricks HF, Pedler BE, Dyhrman ST, Karl DM, Kobližek $M$, et al. Phytoplankton in the ocean use nonphosphorus lipids in response to phosphorus scarcity. Nature. 2009;458:69-72.

83. Galbraith AD, Martiny AC. Simple mechanism for marine nutrient stoichiometry. Proc Natl Acad Sci USA. 2015;112:8199-204.

84. Berge T, Daugbjerg N, Hansen PJ. Isolation and cultivation of microalgae select for low growth rate and tolerance to high $\mathrm{pH}$. Harmful Algae. 2012;20:101-10. 